General Article

\title{
Bacterial Diversity in Aquatic Ecosystems over the Central Himalayas, Nepal: Progress and Future Perspectives
}

\author{
Namita Paudel Adhikari ${ }^{1,2,3}$, Subash Adhikari ${ }^{2,3,4^{*}}$, Ganesh Paudel $^{5}$ \\ ${ }^{1}$ Key Laboratory of Alpine Ecology and Biodiversity, Institute of Tibetan Plateau Research, \\ Chinese Academy of Sciences, Beijing, China \\ ${ }^{2}$ Key Laboratory of Tibetan Environment Changes and Land Surface Processes, Institute of \\ Tibetan Plateau Research, Chinese Academy of Sciences, Beijing, China \\ ${ }^{3}$ University of Chinese Academy of Sciences, Beijing, China \\ ${ }^{4}$ Janapriya Multiple Campus, Tribhuvan University, Pokhara 33700, Nepal \\ ${ }^{5}$ Institute of Forestry, Tribhuvan University, Pokhara 33700, Nepal \\ *Corresponding Author: sadhikari@itpcas.ac.cn
}

\begin{abstract}
Article History
Received 20 April $2019 \quad$ Revised 8 July $2019 \quad$ Accepted 12 November 2019
\end{abstract}

\begin{abstract}
Nepal hosts a large area of freshwater aquatic ecosystem including glacier associated system like glacier-fed streams and lakes as well as stream fed lowland lakes. Bacteriological studies are very important in aquatic ecosystems as bacteria are the major participants in biogeochemical cycles and food web structures. This study reviewed available literature in bacteriological studies of aquatic ecosystems in the Central Himalayas, Nepal and revealed that such studies are very limited. Thus, we conclude that future research works need to proceed through the latest molecular methods with high throughput technique using multiple environmental factors in the aquatic ecosystem.
\end{abstract}

Keywords: Aquatic ecosystems, Bacteria, Central Himalayas, Nepal

(C) The Author, published by JRCC, Janapriya Multiple Campus

Janapriya Journal of Interdisciplinary Studies (Jjis), volume VIII, 2019 
Namita Paudel Adhikari, Subash Adhikari and Ganesh Paudel

\section{Introduction}

An aquatic ecosystem is broadly categorized into freshwater and marine ecosystem based on the salt concentration. The aquatic ecosystem in which the dissolved salt concentration is less than one percent is called a freshwater ecosystem. Nepal, being a land-locked country only hosts the freshwater ecosystem. Some of the aquatic ecosystems of Nepal are lakes, rivers, marshes, and glaciers (https://gold.jgi.doe.gov/distribution\#Classification). Nepal is located in the central part of the Himalayas, with a large number of glaciers, glacier-fed lakes, and streams. Previous studies have estimated that there are altogether 6000 rivers in Nepal with a total drainage area of 194,471 sq.km. Based on the 2001 inventory, there are 3252 glaciers in Nepal with a total area of 5324 sq. km, whereas 2010 inventory identified 3808 glaciers with an area of 4212 sq. km (Bajracharya, And, \& Shrestha, 2011). Similarly, the lake inventory in Nepal uncovered that there are more than 500 lakes with area $<1$ ha (Bhuju, Sharma, Jha, \& Gaire, 2012). Nepal can be broadly divided into four major river systems (Fig. 1) from east to west: the Koshi River, the Gandaki, the Karnali and the Mahakali River draining in the eastern, central, western and far western region, respectively. All these rivers are originated in glaciated mountains and ultimately drained into Ganges River in India. Each of the river basins comprises a large area of glacier and lakes. Bacteria act as the major participants in biogeochemical cycles of aquatic ecosystems (Gucht et al., 2007; Peter et al., 2014). Especially in glacial ecosystems (Fig.2) where other organisms cannot grow and proliferate, they solely act as the biogeochemical integrators as well as food-web structures (Boetius et al., 2015; Adhikari et al., 2019a).

Owing to the major participants in aquatic systems, bacteriological studies in respective habitat is very important. Numerous abiotic and biotic factors (e.g., temperature, oxygen, $\mathrm{pH}$, conductivity, water transparency, organic matter concentration, biodegradable nutrients, water current, Bacteriophages, Zooplanktons, Chlorophyll $a$ (Chla) content are the factors affecting microbial communities in aquatic habitat (Beier et al., 2008; Lliro et al., 2014; Hayden and Beman, 2016). It is very essential to identify and characterize bacterial community to get the information about the ecological niches of bacteria in freshwater bodies (Shafi et al., 2017) and Janapriya Journal of Interdisciplinary Studies (Jjis), volume VIII, 2019 
assess the impact of anthropogenic activities (Wang et al., 2017) as well as the status of pollutants in water bodies (Unno et al., 2012). Due to the short generation time, bacteria can rapidly respond to the small change in environmental conditions. That is why; they can be used as an important model in the study of global climate change (Adhikari et al., 2019a).

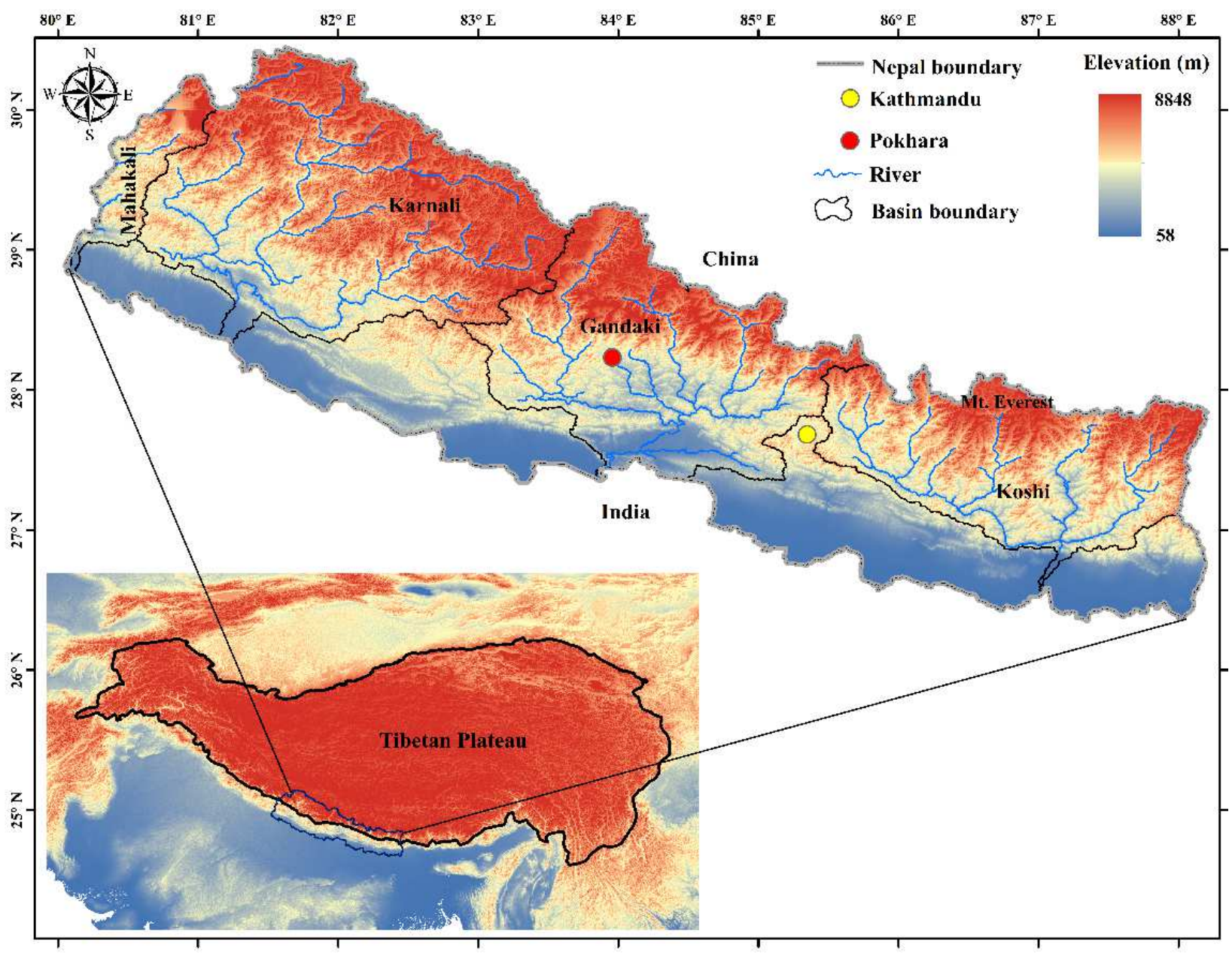

Figure1. Major river basins of Nepal

Despite the fact that microbiological studies are very important in the aspects of environment and ecosystem, a review of the literature indicated that such studies are very limited in the Central Janapriya Journal of Interdisciplinary Studies (Jjis), volume VIII, 2019 
Himalayas, Nepal. Thus, this paper aimed to review previous studies on bacterial diversity in Nepal as well as future research perspectives.

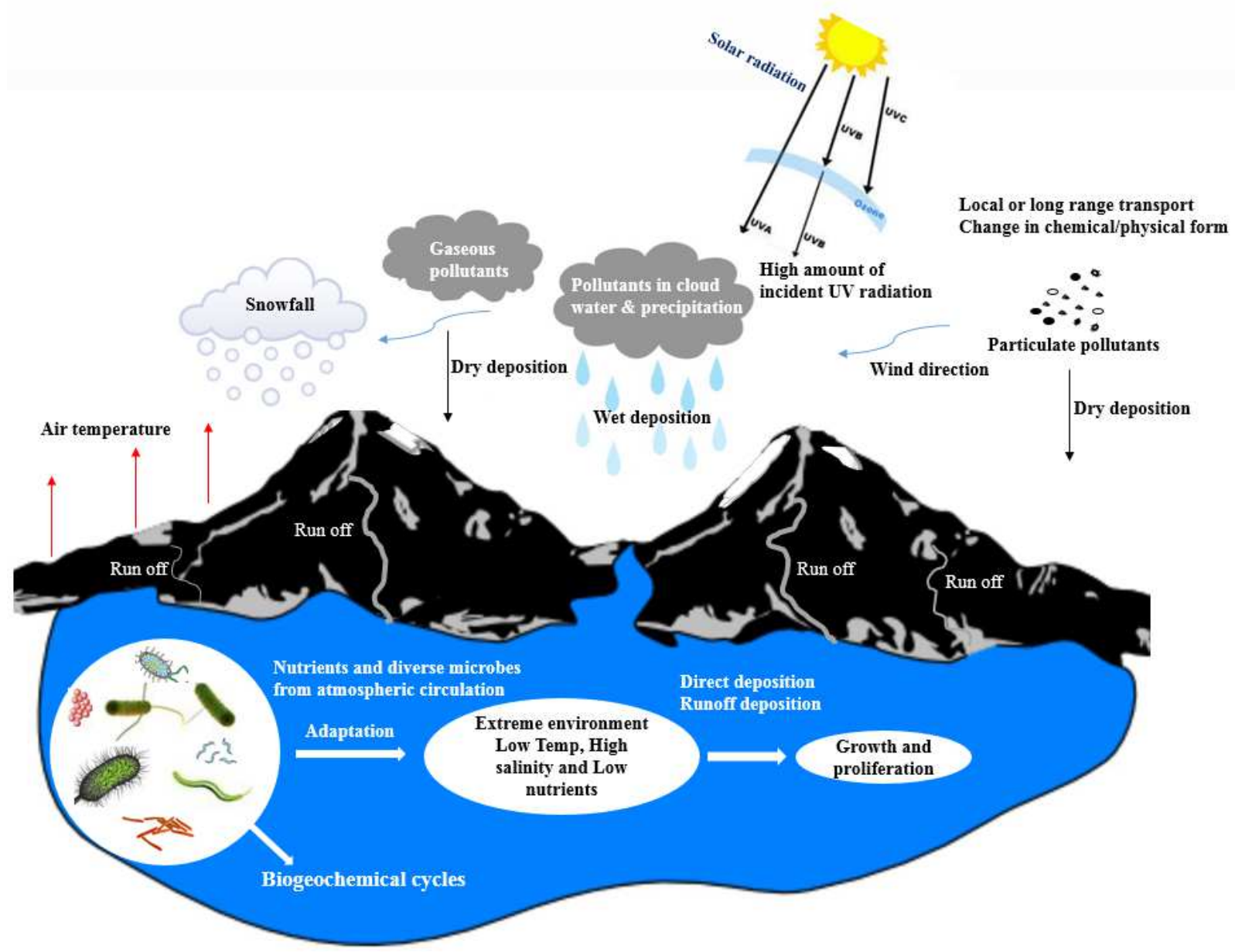

Figure 2. An example of an aquatic ecosystem in the alpine region indicating the role of bacteria and their sources (adopted from Adhikari et al., 2019a)

\section{Progress in bacterial diversity studies in Nepal}

Though microbial ecological studies are not enough in Nepal, bacterial diversity studies in Nepal was started as early as in 1988 by Japanese Scientists (Konda et al., 1988).The research investigated by Konda et al. (1988), in the three subtropical lakes (listed as a Ramsar site in 
2016) of Pokhara valley reported the community of bacteria belonging to genera Pseudomonas, Flavobacterium and Corynebacterium in the water while the genera Bacillus in sediment samples. Authors used nucleopore filters of pore size $3 \mu \mathrm{m}$ to separate particle-associated and free-living bacteria. However, the composition of water in those lakes is completely changed with rapid urbanization and high anthropogenic activities. Furthermore, the authors used a culture-based method which reveals low coverage value (Muyzer, 1999), and the results obtained may not be fully reasonable intherecent context. Study of European scientists (Sommaruga \& Casamayor, 2009) using DGGE as molecular tool in remote lakes of Khumbu region, Nepal, the windward side of Tibetan Plateau (Dong, Jiang, Yu, Liu, \& Zhang, 2010) revealed Betaproteobacteria and Bacteroidetes as the dominant group along with several ubiquitous bacterial groups supporting the bacterial cosmopolitanism in Third Pole lakes. Authors obtained high bacterial load in turbid lakes than in the transparent ones supporting that the limiting factor to shape out the bacterial diversity of alpine lakes is incident UV radiation.

Study of Liu et al., (2011) in moraine lake and a glacial stream of Yala Glacier towards the southern slope of Mount Everest reported the dominance of Bacteroidetes, Betaproteobacteria, and Actinobacteria. Authors used clone library method as the biological analysis tool and noticed the difference in bacterial communities towards the southern slope and the northern slope of Mount Everest and justified that this type of pattern may be due to different climatic, atmospheric and environmental conditions.

Nepal Himalaya is located in the central part of Himalaya Karokaraman, thus attracting several scientists for microbiological studies. Azzoni and Colleagues (Azzoni et al., 2018) did a comprehensive study in four glaciered areas including the Khumbu Valley, Nepal using the Illumina miseq, a type of next-generation sequencing method as the biological analysis tool. Bacterial communities in four glaciated regions differed significantly with each other. Authors reported that Khumbu Valley hosted a significantly higher number of OTUs among four sites. This may be due to the proximity of the Himalayan range to highly polluted areas in the IndoGangetic Plain (IGP). Bacterial members of the order Burkholderiales contributed for more than Janapriya Journal of Interdisciplinary Studies (Jjis), volume VIII, 2019 
$50 \%$ of the total bacterial abundance in Khumbu Glacier. Some genera of this order, i.e. Polaromonas, Comamonas, and Limnohabitans are aerobic anoxygenic phototrophs and can use carbon monoxide as a source of energy (Franzetti et al., 2016).

Bacteria in river survive as free-living, particle-attached, and free-living with differences in metabolism as well as activities. A microbiological study in Koshi River, the largest river of Nepal (Adhikari et al., 2019b) posted that bacterial community composition along the tributaries and mainstream are different. Tributaries with comparatively lower human activities harbored the higher abundance of spore-formingbacteria; meanwhile, the mainstream river with higher human activities harbored the higher abundance of fecal indicator and sewage indicator bacteria. The variation of FL bacteria was driven by water physicochemical properties meanwhile that of PA bacteria was explained by geographic distance. All the above studies indicated that only a limited study have been conducted regarding the bacterial diversity in the aquatic habitat of Nepal (Fig. 3).

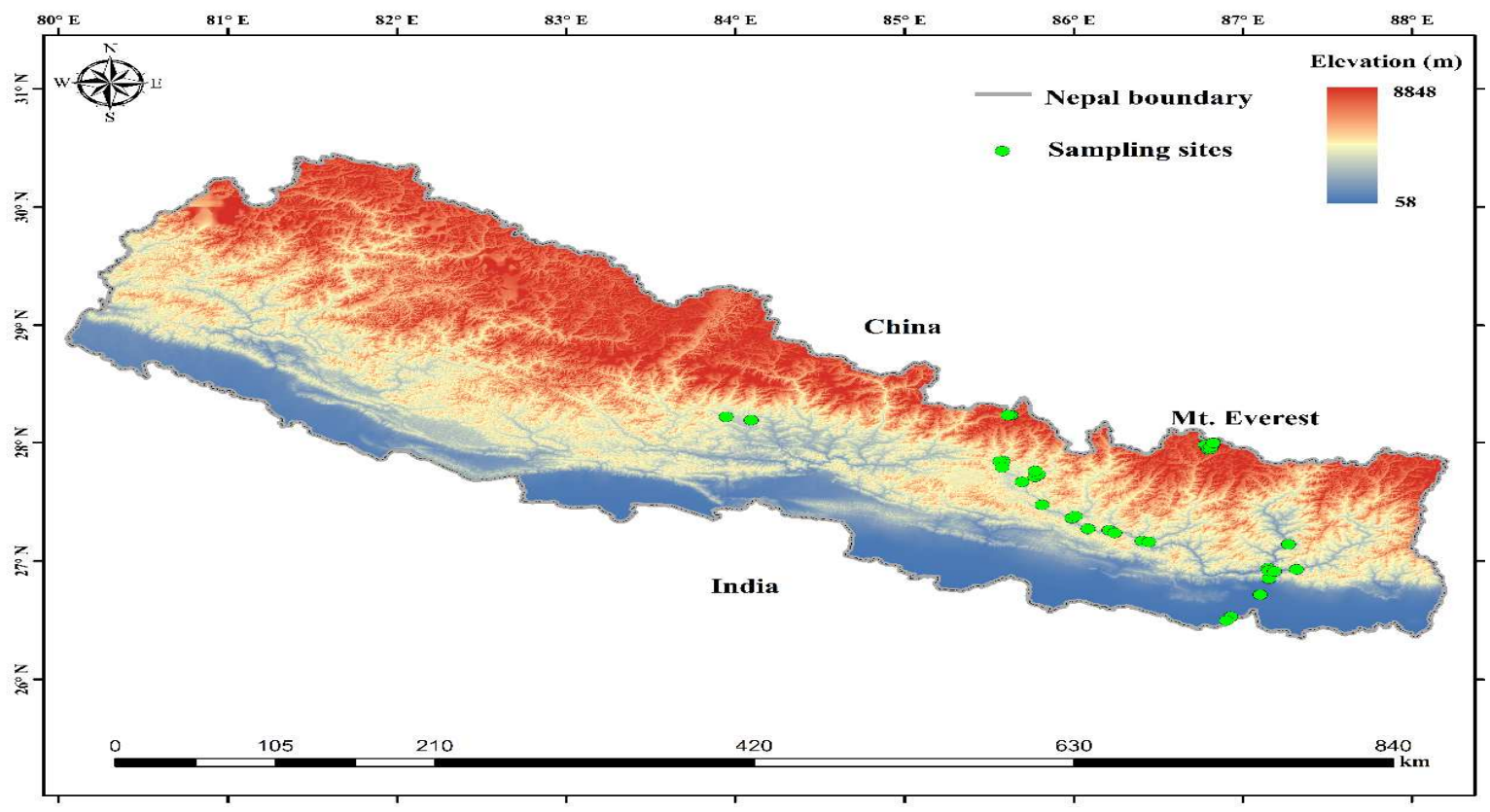

Figure3. Bacterial diversity study in Nepal Himalaya that include river, lakes, and glaciers

Janapriya Journal of Interdisciplinary Studies (Jjis), volume VIII, 2019 


\section{Future perspectivesin bacterial diversity studies in Nepal}

Nepal Himalaya is at a high risk of global climate change. Melting glaciers rapidly transport the ice-locked nutrients to the downstream proglacial ecosystem. Bacteriological information can be used as models for the study of climate change.Microorganisms can exclusively control the biogeochemical cycles and food web structure of the cryosphere environment (Boetius et al., 2015). Due to the short generation time, they can rapidly respond to the shifting environmental conditions. Thus, they can be used as important models to study the changing environmental conditions. Due to the climate change induced global warming, Himalayan Glaciers are rapidly retreating in recent years with the cascading effect in the respective proglacial environment. Thus, studies in all glacial habitats i.e. supraglacial, englacial, proglacial, subglacial, and glacial fore fields (Hotaling, Hood, \& Hamilton, 2017)of the rapidly retreating glacier can help to study the microbial response to shifting environmental changes. Given that microorganisms solely control the biogeochemical cycles of glacial ecosystems, such studies are very important.However, the review of published literature indicates that microbiological studies have been conducted in only two glaciers indicating that such studies are lacking in the HimalayaKarakoram region, specifically in the central Himalayas, Nepal. Various research regarding bacterial diversity was conductedin Tibetan Plateau (TP) and adjoining sites but very few in case of Nepal Himalaya. Tibetan Plateau, the water tower of Asia (Fig.4) is the hot spot to study global climate changes so understanding the scenario of bacterial diversity and their role in the ecosystem in Nepal Himalaya is very important in scientific community study to understand the complete scenario in TP.

Janapriya Journal of Interdisciplinary Studies (Jjis), volume VIII, 2019 


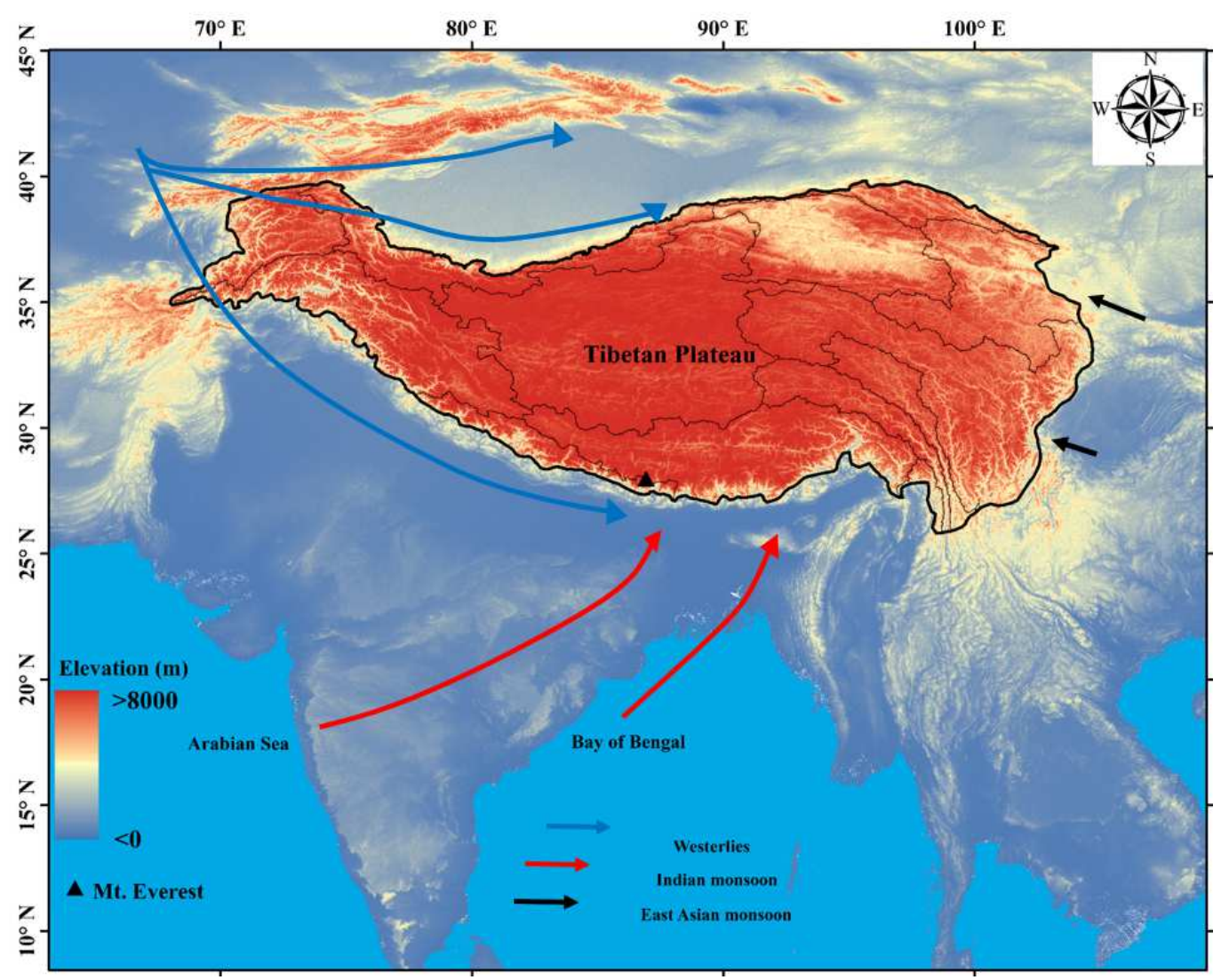

Figure4. Tibetan Plateau and adjoining sites

Despite the great importance of microbiological studies in aquatic ecosystems, the review of the literature revealed that such studies are limited in Nepal. A large number of previous studies used clone library method (Adhikari et al., 2019a), revealing the low coverage value of bacteria, meanwhile, few studies used high throughput next-generation sequencing method. Nevertheless, very few studies used particle-attached and free-living bacteria in their studies though they play a different but important role in the biogeochemical cycling of nutrients (Adhikari et al., 2019b). Thus, future works need to be proceeded using the high coverage molecular tools, incorporating several water physicochemical factors and environmental parameters keeping in consideration of particle-attached and free-living bacteria.

Janapriya Journal of Interdisciplinary Studies (Jjis), volume VIII, 2019 
In microbial community ecology, the first thing we need to know is what are there, and then only we can know their role in the specific biogeochemical pathway of the respective habitat. Thus, though diversity and community composition studies seem to sound general, such works are very important in aquatic ecosystems of Nepal to further understand the role of various diverse bacteria in biogeochemical cycles. However, there exists a huge scientific research gap in the scenario of Central Himalayan, Nepal.

\section{Conclusion}

This review aimed to understand the scenario of microbiological studies in freshwater ecosystems of Central Himalayan, Nepal. Based on the review of previous literature, it is obvious that microbiological studies are limited. There are several related studies in China and the Indian Himalayas. To understand the complete diversity from lowlands to high altitude Tibetan Plateau, the study in Nepal Himalaya is quite essential. Nepal Himalaya is the transit zone for lowlands and TP, therefore, complete study and the exact mechanism cannot be identified unless enough studies emphasized in Nepal. Thus, future research should be accentuated in several aquatic ecosystems of Nepal using the relevant molecular tools and underlining on various type of bacteria in the aquatic ecosystem.

\section{References}

Azzoni, R. S., Tagliaferri, I., Franzetti, A., Mayer, C., Lambrecht, A., Compostella, C., ... Ambrosini, R. (2018). Bacterial diversity in snow from mid-latitude mountain areas: Alps, Eastern Anatolia, Karakoram and Himalaya. Annals of Glaciology, 59 (77), 10-20. https://doi.org/10.1017/aog.2018.18

Bajracharya, S. R., And, S. B. M., \& Shrestha, F. (2011). Glaciers Shrinking in Nepal Himalaya, Climate Change - Geophysical Foundations and Ecological Effects. In B. Juan (Ed.), IntechOpen (p. 13). www.intechopen.com. https://doi.org/http://dx.doi.org/10.5772/57353

Janapriya Journal of Interdisciplinary Studies (Jjis), volume VIII, 2019 
Beier, S., Witzel, K., \& Max-planck-instituts, L. F. (2008). Bacterial Community Composition in Central European Running Waters Examined by Temperature Gradient Gel Electrophoresis and Sequence Analysis of 16S rRNA Genes. Applied and Environmental Microbiology, 74(1), 188-199. https://doi.org/10.1128/AEM.00327-07

Bhuju, D. R., Sharma, S., Jha, P. K., \& Gaire, N. P. (2012). Scientific Discourse of Lakes in Nepal. Nepal Journal of Science and Technology, 13(2), 147-158.

Boetius, A., Anesio, A. M., Deming, J. W., Mikucki, J. A., \& Rapp, J. Z. (2015). Microbial ecology of the cryosphere: Sea ice and glacial habitats. Nature Reviews Microbiology, 13(11), 677-690. https://doi.org/10.1038/nrmicro3522

Dong, H., Jiang, H., Yu, B., Liu, X., \& Zhang, C. (2010). Impacts of environmental change and human activity on microbial ecosystems on the Tibetan Plateau, NW China. GSA Today, 20(6), 4-10. https://doi.org/10.1130/GSATG75A.1

Franzetti, A., Tagliaferri, I., Gandolfi, I., Bestetti, G., Minora, U., Mayer, C., ... Ambrosini, R. (2016). Light-dependent microbial metabolisms drive carbon fluxes on glacier surfaces. ISME Journal, 10(12), 2984-2988. https://doi.org/10.1038/ismej.2016.72

Gucht, K. Van Der, Cottenie, K., Muylaert, K., Vloemans, N., Cousin, S., Declerck, S., ... Meester, L. De. (2007). The power of species sorting: Local factors drive bacterial community composition over a wide range of spatial scales. PNAS, 104(51), 20404-20409.

Hayden, C. J., \& Beman, J. M. (2016). Microbial diversity and community structure along a lake elevation gradient in Yosemite National Park, California, USA. Environmental Microbiology, 18(6), 1782-1791. https://doi.org/10.1111/1462-2920.12938

Hotaling, S., Hood, E., \& Hamilton, T. L. (2017). Microbial ecology of mountain glacier ecosystems: biodiversity, ecological connections and implications of a warming climate. Environmental Microbiology, 19(8), 2935-2948. https://doi.org/10.1111/1462-2920.13766

Konda, T., Nakanishi, M., Sako, Y., Ishida, Y., Shrestha, K., Bhandary, H. R., \& Shrestha, R. L. Janapriya Journal of Interdisciplinary Studies (Jjis), volume VIII, 2019 
Namita Paudel Adhikari, Subash Adhikari and Ganesh Paudel

(1988). Bacterial Numbers and Floras in the Water Sediment of Subtropical Lakes Phewa, Begnas and Rupa in Nepal. Bulletin of Japanese Society of Microbial Ecology, 3(1), 21-28.

Liu, Y., Yao, T., Jiao, N., Tian, L., Hu, A., Yu, W., \& Li, S. (2011). Microbial diversity in the snow, a moraine lake and a stream in Himalayan glacier. Extremophiles, 15(3), 411-421. https://doi.org/10.1007/s00792-011-0372-5

Lliro, M., Inceoglu, O., Garcia-Armisen, T., Anzil, A., Leporcq, B., Pigneur, L., ... Servais, P. (2014). Bacterial Community Composition in Three Freshwater Reservoirs of Different Alkalinity and Trophic Status. PLoS ONE, 9(12), 1-27. https://doi.org/10.1371/journal.pone.0116145

Muyzer G. (1999). DGGE / TGGE a method for identifying genes from natural ecosystems. Current Opinion in Microbiology, 2(3), 317-322. https://doi.org/10.1016/S13695274(99)80055-1

Paudel Adhikari, N., Adhikari, S., Liu, X., Shen, L., \& Gu, Z. (2019). Bacterial Diversity in Alpine Lakes: A Review from the Third Pole Region. Journal of Earth Science, 30(2), 387-396.

Paudel Adhikari, N., Liu, Y., Liu, K., Zhang, F., Adhikari, S., Chen, Y., \& Liu, X. (2019). Bacterial community composition and diversity in Koshi River, the largest river of Nepal. Ecological Indicators, 104(May), 501-511. https://doi.org/10.1016/j.ecolind.2019.05.009

Peter, H., Hörtnagl, P., Reche, I., \& Sommaruga, R. (2014). Bacterial diversity and composition during rain events with and without Saharan dust influence reaching a high mountain lake in the Alps. Environmental Microbiology Reports, 6(6), 618-624. https://doi.org/10.1111/1758-2229.12175

Shafi, S., Kamili, A. N., Shah, M. A., Parray, J. A., \& Bandh, S. A. (2017). Aquatic bacterial diversity: Magnitude, dynamics, and controlling factors. Microbial Pathogenesis, 104, 39_ 47. https://doi.org/10.1016/j.micpath.2017.01.016

Janapriya Journal of Interdisciplinary Studies (Jjis), volume VIII, 2019 
Sogin, M. L., Morrison, H. G., Huber, J. A., Welch, D. M., Huse, S. M., Neal, P. R., ... Herndl, G. J. (2006). Microbial diversity in the deep sea and the underexplored "“ rare biosphere ."” Proceedings of the National Academy of Sciences, 103(32), 12115-12120.

Sommaruga, R., \& Casamayor, E. O. (2009). Europe PMC Funders Group Bacterial ‘ cosmopolitanism, and importance of local environmental factors for community composition in remote high-altitude lakes. Freshwater Biology, 55(5), 994-1005. https://doi.org/10.1111/j.1365-2427.2008.02146.

Unno, T., Di, D. Y. W., Jang, J., Suh, Y. S., Sadowsky, M. J., \& Hur, H. (2012). Integrated Online System for a Pyrosequencing-Based Microbial Source Tracking Method that Targets Bacteroidetes 16S rDNA. Environ. Sci. Technol., 46, 93-98.

Wang, P., Wang, X., Wang, C., Miao, L., Hou, J., \& Yuan, Q. (2017). Shift in bacterioplankton diversity and structure : Influence of anthropogenic disturbances along the Yarlung Tsangpo River on the Tibetan Plateau , China. Scientific Reports, 7(12529), 1-11. https://doi.org/10.1038/s41598-017-12893-4

Janapriya Journal of Interdisciplinary Studies (Jjis), volume VIII, 2019 